DOI: $10.17951 /$ rh.2018.46.321-333

\author{
Jakub Muchowski \\ (Uniwersytet Jagielloński w Krakowie) \\ https://orcid.org/0000-0003-1193-6966
}

\title{
Heteronomizacja pola historiograficznego we współczesnej Polsce. Analiza Forum Badaczy Dziejów Najnowszych
}

\author{
Heteronomization of the Field of History in Contemporary Poland. \\ An Analysis of the Forum of Contemporary History Scholars
}

\begin{abstract}
STRESZCZENIE
Artykuł jest analizą współczesnej polskiej nauki historycznej z punktu widzenia socjologii wiedzy. Jej celem jest rozpoznanie wagi przywiązywanej przez polskich współczesnych badaczy historii najnowszej do idei autonomii dyscypliny historii oraz odpowiedź na pytanie, jak rozumieją to pojęcie. Analiza obejmuje wypowiedzi uczestników warszawskiego Forum Badaczy Historii Najnowszej z 10 grudnia 2016 r. Debata, którą zorganizowano, aby omówić naruszenia granic dyscypliny dokonane przez samych badaczy oraz zewnętrznych aktorów, dostarcza wielu głosów oferujących wgląd w rozumienie własnego profesjonalizmu przez polskich historyków. Komentuję je, korzystając z teorii pola Pierre’a Bourdieu, a zwłaszcza pojęcia ",autonomii”. Moja uwaga koncentruje się na obserwowanych przez uczestników debaty formach heteronomii, generowanych przez cztery główne siły zewnętrzne przekraczające granice pola: władzę polityczna, media, edukację i społeczeństwo. Analiza wskazuje na silne przywiązanie wszystkich uczestników debaty - bez względu na stanowisko zajmowane w dyskusji - do idei autonomii i pozwala opisać wiele sposobów rekonfiguracji jej rozumienia umożliwiających z jednej strony zachowanie statusu obrońcy niezależności dyscypliny, a z drugiej artykulacje własnej wizji badań historycznych.
\end{abstract}

Słowa kluczowe: autonomia, heteronomia, Forum Badaczy Dziejów Najnowszych, teoria pola naukowego, Pierre Bourdieu

W Warszawie 10 grudnia 2016 r. odbyło się Forum Badaczy Dziejów Najnowszych, podczas którego ponad 30 historyków, w tym wielu cieszących się wysokim uznaniem w środowisku, wypowiedziało się na temat naruszeń autonomii nauk historycznych we współczesnej Polsce ${ }^{1}$. W reakcji na apel

1 Okoliczności i organizację spotkania szczegółowo i rzetelnie omawia w swoim sprawozdaniu Andrzej Czyżewski: Pesymizm sprzecznych tez, czyli co dalej? Kilka uwag o „Forum 
organizatorów w kolejnych miesiącach kilku kolejnych badaczy dołączyło swoje uwagi w formie niedługich tekstów ${ }^{2}$. Wytworzono w ten sposób bogaty zespół doraźnych, nierzadko emocjonalnych komentarzy artykułujących zarówno intuicje i spostrzeżenia, jak i wypracowane propozycje teoretyczne dotyczące niezależności dyscypliny historii. Materiał ten wydaje się szczególnie cenny dla badania socjologii wiedzy współczesnej polskiej historiografii.

Skoro przedmiotem debaty był konflikt wokół autonomii nauki, narzędziem analizy, które samo się nasuwa, jest teoria pola społecznego Pierre'a Bourdieu. Wypracował ją badając uniwersum francuskiej akademii, a w centrum jej słownika umieścił opozycję autonomii i heterono$\mathrm{mii}^{3}$. Zadanie opisu pola polskiej historiografii, podsuwane przez jednego z komentatorów debaty ${ }^{4}$, to olbrzymie przedsięwzięcie obejmujące omówienie jego struktury, dynamiki, form heteronomii i określenie habitusu jego uczestników. Wymagałoby zatem zebrania i opracowania nieporównywalnie większej liczby danych i byłoby możliwe do przeprowadzenia przez zespół badawczy dysponujący finansowym wsparciem oraz dużymi zasobami czasu. Tutaj, korzystając z wyjątkowej okazji pojawienia się korpusu danych, który w tego typu przedsięwzięciach badacze na ogół sami muszą wytworzyć, zaproponuję jedynie wstępną analizę pola, skoncentrowaną na wypowiedziach historyków dotyczących naruszających go

historyków dziejów najnowszych" (Warszawa 10.12.2016 r.), "Sensus Historiae” 2016, 24, 3, s. 265-276.

2 Nagranie z całego spotkania znajduje się na stronie Polskiego Towarzystwa Historycznego: http://pth.net.pl/aktualnosci/200 [dostęp: 11 V 2018]. Ponadto na stronie PTH jeszcze przed debatą umieszczono artykuł Jana Pomorskiego: J. Pomorski, Polityzacjal mitologizacja historii, czyli w czym neuronauka (i metodologia) może pomóc badaczowi historii najnowszej?, po niej zaś komentarze Piotra Briksa, Andrzeja Czyżewskiego (wspomniany w przypisie 1) i Wojciecha Wrzoska (który poza uwagami do debaty przesłał również swój artykuł: Tezy o względności historycznej. W poszukiwaniu fundamentów dla pokojowego kultywowania niewspótmiernych obrazów przeszłości, „Nauka Polska. Jej Potrzeby, Organizacja i Rozwój" 2016, 25 [50], s. 25-35). Wspomniane wypowiedzi można znaleźć pod adresem: http:// pth.net.pl/artykuly-i-polemiki/forum-badaczy-dziejow-najnowszych [dostęp: 11 V 2018].

3 Por. przede wszystkim: P. Bourdieu, Homo Academicus, przeł. P. Collier, Stanford 1988; idem, Reguty sztuki. Geneza i struktura pola literackiego, przeł. A. Zawadzki, Kraków 2007 (wyd. II); idem, L.J.D. Wacquant, Zaproszenie do socjologii refleksyjnej, przeł. A. Sawisz, Warszawa 2001, s. 76-99, 100-130.

4 Andrzej Czyżewski w swoim komentarzu kompleksowo opisał debatę, używając kategorii, które wyłaniały się z samych wypowiedzi uczestników. Zasugerował również przeprowadzenie analizy pola historiografii przy użyciu teorii P. Bourdieu. Wykorzystanie jej do skomentowania ma tę przewagę nad znakomitą propozycją A. Czyżewskiego, że pozwala uchwycić, dostrzeżone przez niego, lecz w niewielkim stopniu omówione silne przywiązanie do idei autonomii historii obecne w wypowiedziach badaczy biorących w obronę niektóre formy naruszenia pola dziedziny przez władzę (ujętych przez niego w etykietę "legaliści”). 
form heteronomii ${ }^{5}$. Sądzę też, że niniejszy artykuł może być kolejnym głosem w opisywanej tu debacie o autonomii nauk historycznych w Polsce.

W wykładni Paula Arona, komentatora prac P. Bourdieu, autonomia pola ma trzy wymiary. Po pierwsze, można mówić o autonomii strukturalnej, która dotyczy zakreślenia obszaru pola i osadzenia go w kontekście innych sfer społecznych, a także jego społecznej recepcji. Po drugie, można ją traktować jako narzędzie dyskursywne, po które aktorzy i instytucje sięgają gdy granice pola zostają naruszone z zewnątrz. Pojęcie autonomii służy wówczas konsolidacji uczestników pola i wykorzystywane jest do przygotowania planu oporu wobec ekspansywnych praktyk politycznych, ekonomicznych czy religijnych. Nie wszyscy aktorzy pola gromadzą się wokół hasła autonomii, co umożliwia niektórym aktorom odróżnienie się od tych, którzy poddają się czynnikom heteronomicznym. Wreszcie po trzecie, autonomia jest również urządzeniem do prowadzenia rywalizacji $\mathrm{z}$ innymi aktorami $\mathrm{w}$ obrębie tego samego pola i gromadzenia kapitału symbolicznego, również wówczas, gdy przestrzeni ich produkcji nie zakłócają naciski zewnętrzne. W tym znaczeniu autonomia służy jako argument, za pomocą którego producenci, w tym wypadku wiedzy historycznej, należący do tego samego pola krytykują się nawzajem, dezawuują swoje przedsięwzięcia badawcze i strategie działania, by modyfikować lub umocnić hierarchię dyscypliny ${ }^{6}$.

Dwie skrajne postawy, jakie mogłyby zaistnieć w polu, to bezkrytyczne podporządkowanie się siłom heteronomii oraz wyparcie się podlegania ich wpływom w imię całkowitej autonomii naukowej. Niemniej jednak $\mathrm{w}$ polu naukowym obie raczej nie występują w czystej postaci - dominuje forma pośrednia. Na poziomie deklaracji przeważająca większość aktorów będzie się jednak opowiadać za autonomią pola, bowiem pozycja $\mathrm{w}$ jego ramach wynika w zasadniczej mierze $\mathrm{z}$ uznania, które może płynąć tylko od innych jego uczestników. Ten zaś, kto odwołuje się do autorytetu zewnętrznego, dyskredytuje się w oczach konkurentów. Ponadto, walczących między sobą o ustalenie hierarchii oraz dystrybucję zasobów łączy wspólny interes utrzymania pola jako całości oraz podniesienia jego pozycji względem innych pól. Wobec tego spór między aktorami będzie

5 Ostatnio kompleksowego opisu polskiego pola literackiego podjęła się grupa literaturoznawców. Rezultatem ich prac są dwa tomy tekstów (oraz antologia przekładów artykułów z socjologii literatury): A. Palęcka et al., Literatura polska po 1989 roku w świetle teorii Pierre'a Bourdieu. Raport z badań, Kraków 2014; Literatura polska po 1989 roku w świetle teorii Pierre'a Bourdieu. Podręcznik, red. G. Jankowicz, P. Marecki, M. Sowiński, Kraków 2015.

6 Por. P. Aron, Sur le concept d'autonomie, „Discours social/Social Discourse” 1995, 3-4, s. 64-65. Zob. też G. Jankowicz, Formy heteronomii. Polskie pole literackie po 1989 roku i jego relacje z innymi polami społecznymi, w: A. Palęcka et al., op. cit., s. 20-21. 
na ogół dotyczył wizji ideału nauki, ponieważ to właśnie ona określa hierarchię pola, a zatem rozprzestrzenienie jej i uzyskanie akceptacji pozwala zmieniać lub wzmacniać istniejące układy pozycji

Według P. Bourdieu, jak zwracają uwagę jego komentatorzy, rywalizacja o kapitał symboliczny w obrębie pola nie jest zachowaniem cynicznym. Habitus poszczególnych aktorów, sterujący ich funkcjonowaniem w polu, nie jest strukturą do końca uświadomiona stąd ich działania nie należy odczytywać jako rezultatu cynizmu. W ten sposób jednak można rozumieć gesty heterogeniczne, czyli sięganie do innych pól, aby pozyskać zgromadzony w nich kapitał, które podejmuje się bez zważania na reguły gry własnego pola ${ }^{8}$.

Analiza wypowiedzi Forum Badaczy Dziejów Najnowszych, omawiająca wykorzystanie argumentu autonomii nauki do rywalizacji wewnątrz pola zapowiada się produktywnie, jeżeli weźmiemy pod uwage komentarze Jana Olaszka o obwinianiu młodych badaczy o nieostrożne związki z mediami, Henryka Głębockiego o własnej karierze naukowej jako „zwykłego przeżuwacza archiwów, który nigdy nie kierował żadnym instytutem i do dzisiaj podlega swoim kolegom" czy Piotra Briksa o spychaniu części historyków „poza margines debaty publicznej” i ślepocie "mainstreamowych historyków” zajmujących wysokie pozycje na uniwersytetach i w mediach. Podobnemu odczytaniu łatwo poddają się wypowiedzi debatujących artykułujące reguły pola, które przybierają formę "głosu porządku" wzywającego do wygaszania emocji, powołującego się na prawdę historyczną czy eksponującego autorytety. Omówienie wewnętrznej dynamiki pola historii, jak już wspomniałem, wymagałoby jednak obszerniejszych badań.

Pierre Bourdieu poświęcił mało uwagi opisowi działania zewnętrznych bodźców i odrzucał ich pozytywny skutek, w tym np. napędzanie rozwoju pola czy otwieranie drogi do stworzenia nowych hierarchii poznawczych ${ }^{9}$. Wystąpienia uczestników warszawskiego Forum to m.in. komentarze do zaobserwowanej przez historyków heteronomizacji nauk historycznych. Badacze zwracają uwagę na ingerencję w strukturę pola przez media, politykę, edukację i społeczeństwo oraz niekiedy wskazuja, że skutkują one jego rozbiciem. Postaram się je omówić.

7 Por. P. Bourdieu, Specyfika dziedziny naukowej i społeczne warunki rozwoju wiedzy, przeł. E. Neyman, w: Kryzys i schizma. Antysjentystyczne tendencje w socjologii współczesnej, t. 2, red. E. Mokrzycki, Warszawa 1984, s. 94-95.

8 Por. P. Bourdieu, The Field of Cultural Production. Essays on Art and Literature, New York 1993, s. 79, 95-96; idem, Reguty sztuki, s. 218-219; G. Jankowicz, op. cit., s. 82-83.

9 Por. D. Hesmondhalgh, Bourdieu, the Media and Cultural Production, "Media Culture \& Society" 2006, 2, s. 217-223; G. Jankowicz, op. cit., s. 21-22. 
Zdaniem P. Bourdieu siłą społeczna, która może zmieniać hierarchie wewnątrz pola naukowego dystrybuując w nim kapitał symboliczny, są media prasowe i telewizyjne. Podobnie uważali uczestnicy Forum. Andrzej Friszke podkreślał, że historyków niepokoi to, co o przedmiocie ich badań mówią politycy i dziennikarze, podważając ustalenia profesjonalnych historyków. Paweł Machcewicz zauważył jednak, że historycy powinni uznać rolę mediów, ale także władz państwowych i organizacji pozarządowych, w wytwarzaniu i przekazywaniu wiedzy historycznej, przy założeniu, że wszystkie te podmioty respektują swoją autonomię i prawo do istnienia w przestrzeni publicznej. Głosy te dowodza, że zaangażowanie mediów w produkcję i przekaz wiedzy historycznej rodzi obawy historyków o utratę autorytetu ich pola naukowego, która jednak równoważona jest przez przekonanie, że nie mają monopolu na wypowiadanie się o przeszłości i uznają uczestnictwo w debacie historycznej aktorów związanych z innymi polami, w tym mediów. Henryk Głębocki natomiast zauważa, że media, w tym wielkie międzynarodowe koncerny, które pozostają "poza naszym zasięgiem”, od dawna "kreują nasze wizje świata i kształtują dyskusje naukowców", hamując rozwój niektórych kierunków badań. Jeszcze dalej poszedł Wojciech Wrzosek, stwierdzając, że "to politycy, publicyści i dziennikarze wyznaczyli problemy poruszane przez moderatorów i dyskutantów warszawskiego spotkania". Obydwa komentarze sugeruja, że pole mediów stale narusza niezależność przestrzeni nauk historycznych z powodu swojego przemożnego - tylko częściowo rozpoznawanego przez samych badaczy - wpływu na ogół rzeczywistości społecznej, w której historycy uczestniczą. Pierwszej z tych wypowiedzi wydaje się towarzyszyć oczekiwanie, że to polityka historyczna władzy państwowej pozwoli zneutralizować wpływ mediów (przede wszystkim tych międzynarodowych), drugą zaś można odczytać jako wezwanie do rozwijania samoświadomości badań historycznych, obejmującej również oddziaływanie zewnętrznych sił, którym mimowolnie się poddają.

Kilku dyskutantów podjęło zagadnienie prasowych i telewizyjnych wypowiedzi historyków, które łamią reguły nauk historycznych. Krzysztof Mikulski ujął zagadnienie formułą: ,,[...] czy historyk jako naukowiec i historyk jako polityk, to jedna czy dwie różne osoby?". Te niejasne słowa wyrażają niepokój aktywnością niektórych aktorów w dwóch obiegach społecznych, którzy zdobywają kapitał symboliczny poza macierzystą przestrzenią. Obawy te próbował rozwiać Andrzej Nowak, stwierdzając, że historyk, który wypowiada się w formach publicystycznych, rezygnuje w nich ze swojego autorytetu naukowego i jego głos jest wówczas równoważny głosowi zwykłego Kowalskiego. Łatwo jednak zbić ten argument, zauważając, że wspomniany gest rezygnacji z autorytetu, zwłaszcza gdy 
wykonuje go znany historyk, nie zostanie uwzględniony w społecznym odbiorze jego wypowiedzi. Z kolei Wojciech Roszkowski zachęca historyków do zabierania głosu $\mathrm{w}$ polu publicystyki, zamiast oskarżania polityków o naruszanie autonomii historii i apeluje, aby „spierali się z politykami na płaszczyźnie politycznej, a nie zarzucali im, że gwałcą warsztat historyka". Sądzę jednak, że apel ten nie zyska aprobaty innych członków cechu, gdyż odciagnie ich od tego habitus naukowca. Ciągłe przechodzenie części historyków z jednego pola do drugiego może bowiem podważać przekonanie pozostałych o celowości podporządkowywania się logice pola i podejmowanych przez nich prac badawczych. Odbywa się to kosztem illusio, czyli współdzielonej z innymi wiary w wartość praktyki, $\mathrm{w}$ tym przypadku historycznej i związanych z nią rezultatów poznawczych oraz społecznych ${ }^{10}$. Odpowiedź na tę formę heteronomii pola podsuwa Dariusz Stola, proponując kodeks postępowania historyka wypowiadającego się poza nośnikami należącymi do pola, przestrzegający go przed praktykami, które naruszałyby reguły gry panujące w sferze nauki. Realizacja tej sugestii nie tylko wzmacniałaby autorytet pola historii, ale rozszerzałaby też obszar oddziaływania reguły nauk historycznych poza jego granice.

Dominująca liczba wypowiedzi debaty na Forum Badaczy Dziejów Najnowszych dotyczyła heteronomicznych przekroczeń wychodzących z pola polityki, a jako jej główną formę wskazywano politykę historyczną. Polityka historyczna, jak zauważył Marcin Zaremba, „instrumentalizuje i banalizuje" wiedzę historyczna, a więc, można dopowiedzieć za P. Bourdieu, osłabia autorytet pola, trywializując ustalenia profesjonalistów i stwarzając wrażenie zależności historyków od władzy. Ponadto, po prostu wywiera naciski na historyków, jak dodał Marcin Kula. Paweł Machcewicz zwrócił uwagę, że ingerencje władzy naruszają nie tylko ustalone $\mathrm{w}$ granicach pola hierarchie faktów i narracji, ale również stratyfikację metod badawczych, za pomocą których fakty te są opracowywane, a narracje konstruowane. $W$ ten bowiem sposób należy rozumieć podważenie wiarygodności i użyteczności komparatystyki historycznej, będące składnikiem ataku na wystawę stałą Muzeum II Wojny Światowej w Gdańsku.

Rafał Łatka (zgodzili się z nim Piotr Briks i Wojciech Roszkowski) wskazywał jednak, że polityka historyczna istnieje od zawsze i będzie istnieć, co można rozumieć jako rozpoznanie, że pole historii nigdy nie

10 Por. komentarz Bernarda Lahire'a: The Double Life of Writers, przeł. G. Wells, „New Literary History" 2010, 2, s. 446; G. Jankowicz, op. cit., s. 40; zob. też P. Bourdieu, Reguty sztuki, s. 260-268, 347-352. 
jest w pełni autonomiczne, a całkowita niezależność jest naiwnym i być może szkodliwym ideałem, skrywającym stałą obecność sił heterogenicznych $\mathrm{w}$ polu. W. Roszkowski z kolei przeniósł zagrożenie pola historii na poziom międzynarodowy, wskazując, że politycy unijni i podążający za nimi historycy naruszają autonomię pola historii europejskiej, podporządkowując je potrzebom ponadnarodowej instytucji. Jednocześnie jednak próbował wyjaśniać, że „polityka historyczna nie narusza autonomii historii, bo jest jak polityka gospodarcza wobec ekonomii jako nauki". Byłaby więc jedynie wzmacnianiem, przekazywaniem i stosowaniem części wiedzy historycznej wybranej przez władzę z różnorodnego zasobu stworzonego przez historyków, przy równoległym zachowaniu, a nawet dalszym rozwijaniu, tego ostatniego.

Paweł Machcewicz, Rafał Wnuk i Krzysztof Persak wskazali również na poważne przekroczenia niezależności instytucji postrzeganych przez historyków jako należące do przestrzeni nauk historycznych, zwłaszcza Muzeum II WŚ i IPN (Instytut Pamięci Narodowej). R. Wnuk alarmował o nieuzasadnionych merytorycznie zmianach personalnych w IPN, a wypowiadający się po nim K. Persak starał się naświetlić charakter tak przeprowadzonego naruszenia. Najpierw zaznaczył, że IPN został ustanowiony przez władze państwowe jako sprofilowana przez instancję polityczną instytucja, która miała zajmować się w swoim głównym nurcie działalności badawczej historią represji i oporu społecznego w komunistycznej Polsce. $\mathrm{W}$ ten sposób o zakresie badań decydują czynniki pozanaukowe, a nie wewnętrzne reguły i dynamika praktyki historycznej, które wymuszałyby podjęcie $\mathrm{w}$ podobnym stopniu zagadnień bezpośrednio związanych z głównym przedmiotem uwagi, np. zjawisko społecznego poparcia dla reżimu. Zaprojektowana przez władze nieumotywowana naukowo dominanta działalności badawczej IPN jest w przekonaniu K. Persaka kłopotliwa, lecz możliwą do zaakceptowania formą heteronomii. Niedopuszczalne są zaś wspomniane przez $\mathrm{R}$. Wnuka bezpośrednie ingerencje w kadry Instytutu i jak dodał K. Persak, zmonopolizowanie Kolegium IPN przez obecne władze czy likwidacja czasopisma Pamieć.pl.

Objęcie polem Muzeum II Wojny Światowej wzbudziło wątpliwości A. Nowaka. Dostrzegał on tu prawomocność innorodnych ingerencji i podkreślał złożoność statusu „instytucji pamięci”, które przeciwstawiał jednoznacznemu charakterowi instytutów historii. W. Roszkowski zajął zbliżone stanowisko, wskazując, że proponowane przez polityków ingerencje w merytoryczną warstwę wystawy należy traktować jako prezentację innego punktu widzenia na historię, a nie polityczną interwencję. Innymi słowy, podważał heteronomiczny charakter interwencji władzy, tworząc wrażenie, że jest ona $\mathrm{w}$ istocie kolejnym elementem pola. Nale- 
ży jednak zwrócić uwagę, że władza, wspierając jedno z podejść badań historycznych, wzmacniając za pomocą swoich zasobów zainteresowanie naukowców określonym zestawem tematów czy opowiadając się za wybraną interpretacją ważnych wydarzeń historycznych, nie podejmuje tych działań powodowana regułami pola historii (np. uzasadniając je naukową argumentacją). Kieruje się raczej regułami pola polityki, w tym potrzebą legitymizacji władzy czy chęcią realizacji wyłonionego w politycznej dyskusji dobra wspólnego. Status muzeów ujednoznacznił P. Machcewicz, wskazując na podobieństwa instytucji pamięci i instytutów historii: po pierwsze, w obu przypadkach mamy do czynienia z tym samym źródłem finansowania - państwem, po drugie zaś, „muzea stają się główną przestrzenią dyskusji historycznej”, więc „,w przestrzeni muzeum powinniśmy przestrzegać tych samych reguł zawodowych, co w pracy akademickiej".

Bardziej czy nawet najbardziej zdecydowaną i wyrazistą formułę niezależności nauk historycznych zgłosili Piotr Majewski i Maciej Janowski, postulując budowanie ",wolnorynkowej historii”, , wolnego rynku idei, na której różne poglądy rywalizują ze sobą w sposób swobodny”. Byłaby to przestrzeń czystej nauki wykluczająca jakiekolwiek interakcje z zewnętrzem, a zwłaszcza polityczne. Analogią dla autonomii nauk historycznych była dla P. Majewskiego i M. Janowskiego autonomia rynku w ujęciu ekonomii liberalnej. Oznacza to, jak sądzę, że rywalizacja historyków o lepszą pozycję w ramach pola ma się rządzić jego wewnętrzną logiką. W jego granicach korekty powinna dokonywać „niewidzialna ręka rynku naukowego", która, podobnie jak „niewidzialna ręka rynku gospodarczego", harmonizuje dążenia badaczy do indywidualnej korzyści i zamienia konkurujące przedsięwzięcia we wspólne dobro pola. Sam jednak M. Janowski, określając „wolnorynkową historię" jako „wyśniony ideał”, powątpiewa w możliwość funkcjonowania takiego pola $\mathrm{w}$ rzeczywistości społecznej. Jan Pomorski, zwracając uwagę na społeczne i neurobiologiczne uwarunkowania wytwarzania historii, wykluczył prawdopodobieństwo zaistnienia czy zbudowania tego ideału. Podważył także zasadność podążania za nim, gdyż z jednej strony zamazuje on obraz funkcjonowania pracy historyka, który przecież działa w złożonych zależnościach społecznych i kulturowych, z drugiej zaś demobilizuje potencjał historyków do angażowania się w kształtowanie wspólnoty.

Ważna dla rozmówców była również złożona relacja między polem historii i edukacji, przy czym w wielu wypowiedziach ten związek konfigurowano z polem polityki. Krzysztof Kawalec mówił o postępującym już od kilkunastu lat ograniczaniu programów nauczania historii, które powodują zmniejszenie jej znaczenia w społeczeństwie (bo „młody człowiek nie przeczyta, jeśli się go do tego nie zmusi"), ale też spadek umie- 
jętności historycznej oceny współczesnej rzeczywistości przez nieprofesjonalistów. Monika Piotrowska-Marchewa zwróciła zaś uwagę na to, że współczesne ograniczenia w edukacji historycznej dotyczą w mniejszym stopniu wielkości zasobu wiedzy, a w większym jego jednorodnego charakteru. Jej zdaniem bowiem program został podporządkowany ujednoliconej, polonocentrycznej, męskiej, etnicznej - Krzysztof Persak dodał, że apologetycznej - narracji.

W ujęciu Pierre'a Bourdieu edukacja jest kluczowym czynnikiem $\mathrm{w}$ procesach strukturyzacji społeczeństwa. W systemach demokratycznych szkoła ma na ogół być narzędziem rekonfiguracji sieci społecznych ukierunkowanych na zrównanie społeczeństwa czy niwelację różnic klasowych. Badacz zauważył jednak, że szkolnictwo zaprzężone do przedsięwzięcia zniesienia nierówności społecznych oraz włączania w przestrzeń wspólnoty nowych grup i jednostek nie działa w pożądany sposób. Rezultaty jego pracy bywają odwrotne, gdyż zamiast znoszenia hierarchii reprodukuje je albo, dokładniej, podważa asymetryczne podziały w jednym miejscu i utrwala je na innym poziomie ${ }^{11}$.

W odpowiedzi na tę diagnozę proponuje się, aby programy nauczania w większym stopniu wyposażały uczniów w kompetencje, w tym wypadku historyczne, dostarczając im nie tylko gotowej wiedzy, ale i umiejętności jej krytykowania oraz wytwarzania. W miejsce reprodukcji istniejących hierarchii, która polegałaby na narzucaniu uczniom jednorodnej narracji historycznej, szkoły mogłyby dostarczać wiedzy o różnych narracjach i wielu wzorach uprawiania historii. Należy jednak zwrócić uwagę, że również ta strategia edukacyjna nie znosi różnic między uczniami, lepiej doposażając tych, którzy z większym kapitałem społecznym i kulturowym trafiają do systemu edukacji ${ }^{12}$.

W relacjach między dyscypliną historii a polem edukacji wytwarza się stałe napięcie, które podtrzymywane jest przez naruszanie przez historyków utrwalanych przez szkołę hierarchii wykładni przeszłości. Z kolei uniwersum historii naruszane jest przez wpływy pola edukacji, gdy w oferowanych programach dostarcza uczniom instrumentów krytyki i produkcji wiedzy historycznej. Opisywany przez M. Piotrowską-Marchewę i K. Persaka nowy program nauczania, skupiający się w większym stopniu na dostarczaniu "konsekrowanej” wiedzy historycznej, a w mniejszym na ćwiczeniu umiejętności badawczych i krytycznych, przyniesie dwie ważne konsekwencje. Po pierwsze, szkoła w bardziej ograniczonej mierze

11 Por. np. P. Bourdieu, J.-C. Passeron, Reprodukcja. Elementy teorii systemu nauczania, przeł. E. Neyman, Warszawa 2006, s. 154-176.

12 Por. ibidem, s. 222-232. 
zrównywać będzie społeczeństwo, po drugie zaś, wymiana między polem historii a polem edukacji będzie bardziej jednostronna, a wspomniane napięcie między nimi ulegnie osłabieniu, gdyż aktorzy spoza akademii nie będą dysponowali kompetencjami do wejścia we względnie równą dyskusję z historykami.

Warto w tym kontekście wspomnieć o mniej licznych wypowiedziach wyrażających obserwacje dotyczące naruszeń pola historii przez niehistoryków zajmujących się historia, którzy przemieszczają się przez pola historii, mediów i polityki, ale w żadnym z nich nie są zakotwiczeni. Zdaniem M. Janowskiego najkorzystniejsza sytuacja dla historyków to taka, w której społeczeństwo nie interesuje się historia, bo praktyki historyczne zwykłych ludzi „spłycają historię i utrudniają pogłębiony spór”. Ta wypowiedź wywołała reakcję P. Briksa i W. Roszkowskiego, którzy wyrażali zadowolenie z zaangażowania społeczeństwa $\mathrm{w}$ historię i nie dostrzegali w nim zagrożenia dla profesji. Argumentowali, że obywatelskie wychowanie człowieka opiera się na poznaniu historii i cieszyli się, że obecnie Polacy chętnie zdobywają wiedzę historyczną, pojawiając się tłumnie na debatach historyków, uczestnicząc w uroczystościach patriotycznych, biorąc udział w grupach rekonstrukcyjnych, w ramach których pogłębiają swoją wiedzę historyczną i prowadzą aktywność edukacyjną. W dyskusji tej obie strony nie biorą pod uwagę możliwości, w której wiedza historyczna wytwarzana jest przez niehistoryków, a nie „spłycana”, przekazywana podczas własnych działań popularyzatorskich, wysłuchiwana podczas debat czy przeżywana podczas uroczystości.

Wskazane formy heteronomii prowadzą w opinii wypowiadających się do rozbicia środowiska i zagrażają spójności, a tym samym autorytetowi pola. Jeśli zaufać treści deklaracji podsumowującej Forum, kluczową formą heteronomii współczesnego pola historii w Polsce dostrzeganą przez jego uczestników jest wpływ sił politycznych. Badacze przeciwstawiają mu konsolidację wokół, po pierwsze, idei niezależności pola historii rządzącego się swoimi wewnętrznymi regułami oraz po drugie, wartości takich jak pluralizm, dialog i wzajemny szacunek.

Deklaracja sugeruje również, że historycy przyznają sobie możliwość ingerencji w pole społeczne dla dobrobytu wspólnoty. Wchodzą tym samym w proponowaną przez P. Bourdieu pozycję naukowca-intelektualisty. Jest to, jak tłumaczy autor Regut sztuki, usytuowanie dwuwymiarowe, zakładające jednocześnie autonomię świata intelektualnego, który udziela historykowi specyficznego autorytetu, i możliwość zaangażowania tego autorytetu $\mathrm{w}$ działanie polityczne. Nie mamy tu więc do czynienia z „nauką czystą" "zamkniętą w wieży z kości słoniowej”, gdyż badacze angażują politycznie swoje unikatowe umiejętności i wiedzę. Jednocze- 
śnie w swej aktywności nie zagrażają autonomii pola, gdyż nie odchodzą $\mathrm{w}$ niej od zasad gry pola naukowego. Budowanie autonomii nauki nie stoi zarazem w sprzeczności z efektywnością polityczną, ale przeciwnie wzmacnia ją, np. zapewniając swobodę krytyki władzy ${ }^{13}$. W tej figurze badacz, interweniując poza polem historii bez naruszenia reguł naukowych, może skutecznie działać w imię szeroko rozumianego dobra wspólnego, inwestując zdobyte $\mathrm{w}$ ramach nauki wyjątkowe kompetencje. Wówczas nie naraża na szwank autonomii i autorytetu pola, a nawet wzmacnia jego pozycję wobec innych pól społecznych.

Jakie praktyki i wiedzę miałyby zawierać interwencje historyków w ogólną przestrzeń społeczną? Pierre Bourdieu nie sformułował swojego opisu natury interwencji naukowca-intelektualisty, ograniczając się do skrótowego omówienia tej figury w kontekście teorii pola naukowego. Odpowiedzi na to pytanie pojawiły się w głosach Jana Pomorskiego i Krzysztofa Kawalca. Pierwszy proponuje nawet dwa typy działania historyka-intelektualisty: negatywny, polegający na dekonstruowaniu mitów i spolityzowanych narracji historycznych krążących w obiegu publicznym, również drogą odtwarzania "gramatyk", które je generuja, i pozytywny, na który składałyby się działania eksponujące (w edukacji publicznej i aktywności popularyzatorskiej) narracje historyczne wzmacniające kapitał społeczny wspólnoty. Jan Pomorski wyjaśnia, że te ostatnie opowiadają o wydarzeniach z dziejów społeczeństwa, w których przywiązanie grupy do wartości, takich jak zaufanie, lojalność, wzajemność i solidarność upodmiotawia je, to jest ośmiela do działania na rzecz dobra wspólnego. W tej sekwencji wydarzeń wzmocniona w swej sprawczości grupa walczy o dobro zbiorowości i wysiłki te kończą się sukcesem ${ }^{14}$. Krzysztof Kawalec jest podobnego zdania o tyle, o ile również uważa, że aktywność profesjonalnych historyków powinna wspierać „,tworzenie klimatu dla angażowania się obywateli w obrębie struktur demokratycznego państwa prawa", a tym, co napędza uczestnictwo społeczeństwa w życiu publicznym, jest podzielany przez nie system wartości.

Na zakończenie tej krótkiej analizy warto zaznaczyć, że istotny problem związany z opisem pozycji naukowca-intelektualisty pozostaje niewidoczny dla propozycji z deklaracji polskich badaczy dziejów najnowszych i oferty z pism Pierre'a Bourdieu. Jest nim nierówny charakter relacji między naukowcami-intelektualistami a ich publicznością. Wysuwane rozumienie tej figury wydają się budować tradycyjne założenia mówią-

13 Por. P. Bourdieu, W imię korporacjonizmu tego, co uniwersalne, w: idem, Reguty sztuki, s. 505-519.

14 Więcej: J. Pomorski, op. cit. 
ce, że zadaniem intelektualisty jest dostarczanie wiedzy o funkcjonowaniu społeczeństwa tym jego członkom, którzy go nie rozumieją. To ujęcie przypomina dawny model marksistowski, w którym ludzie podporządkowani nie rozpoznawali swojej pozycji w zbiorowości w sposób prawidłowy i potrzebowali nauk wytwarzanych przez intelektualistów, aby ich wyzwoliły. Tymczasem wydaje się, że myślenie i działanie na rzecz wyzwolenia, upodmiotowienia zbiorowości czy tworzenia społeczeństwa obywatelskiego i budowania dobra wspólnego musi być zakotwiczone w doświadczeniu i wiedzy ludzi, którzy mają w tych procesach uczestniczyć. Podążanie za tą intuicją wchodzi jednak w silne napięcie $\mathrm{z}$ habitusem naukowców mocno przywiązanych do zasady autonomii pola. Zostaje ona tutaj bowiem wystawiona na ryzyko naruszenia przez sferę społeczną jako przestrzeń formowania własnych reguł i środków wytwarzania oraz przekazywania wiedzy historycznej.

\section{BIBLIOGRAFIA (REFERENCES)}

Aron P., Sur le concept d'autonomie, „Discours social/Social Discourse” 1995, 3-4.

Bourdieu P., Homo Academicus, przeł. P. Collier, Stanford 1988.

Bourdieu P., Reguty sztuki. Geneza i struktura pola literackiego, przeł. A. Zawadzki, Kraków 2007 (wyd. II).

Bourdieu P., Specyfika dziedziny naukowej i społeczne warunki rozwoju wiedzy, przeł. E. Neyman, w: Kryzys i schizma. Antysjentystyczne tendencje w socjologii wspótczesnej, t. 2, red. E. Mokrzycki, Warszawa 1984.

Bourdieu P., The Field of Cultural Production. Essays on Art and Literature, New York 1993.

Bourdieu P., W imię korporacjonizmu tego, co uniwersalne, w: P. Bourdieu, Reguty sztuki. Geneza i struktura pola literackiego, przeł. A. Zawadzki, Kraków 2007 (wyd. II).

Bourdieu P., Passeron L.J.-C., Reprodukcja. Elementy teorii systemu nauczania, przeł. E. Neyman, Warszawa 2006.

Bourdieu P., Wacquant L.J.D., Zaproszenie do socjologii refleksyjnej, przeł A. Sawisz, Warszawa 2001.

Czyżewski A., Pesymizm sprzecznych tez, czyli co dalej? Kilka uwag o „Forum historyków dziejów najnowszych" [Warszawa 10.12.2016 r.], „Sensus Historiae” 2016, 24, 3.

Hesmondhalgh D., Bourdieu, the Media and Cultural Production, "Media Culture \& Society" 2006, 2.

G. Jankowicz, Formy heteronomii. Polskie pole literackie po 1989 roku i jego relacje z innymi polami społecznymi, w: Literatura polska po 1989 roku w świetle teorii Pierre'a Bourdieu. Podręcznik, red. G. Jankowicz, P. Marecki, M. Sowiński, Kraków 2015.

Lahire B., The Double Life of Writers, przeł. G. Wells, „New Literary History” 2010, 2.

Literatura polska po 1989 roku w świetle teorii Pierre'a Bourdieu. Podręcznik, red. G. Jankowicz, P. Marecki, M. Sowiński, Kraków 2015.

Palęcka A. et. al., Literatura polska po 1989 roku w świetle teorii Pierre'a Bourdieu. Raport z badań, Kraków 2014.

Pomorski J., Polityzacja/mitologizacja historii, czyli w czym neuronauka (i metodologia) może pomóc badaczowi historii najnowszej, http://pth.net.pl/artykuly-i-polemiki/forum-badaczy-dziejow-najnowszych [dostęp: 17 I 2019].

The Double Life of Writers, przeł. G. Wells, „New Literary History” 2010, 2. 
Wrzosek W., Tezy o względności historycznej. W poszukiwaniu fundamentów dla pokojowego kultywowania niewspótmiernych obrazów przeszłości, „Nauka Polska. Jej Potrzeby, Organizacja i Rozwój" 2016, 25 (50).

\begin{abstract}
The paper is an analysis of contemporary Polish historical discipline from the standpoint of sociology of knowledge. My goal is to recognize the value ascribed by the contemporary history scholars to the idea of the autonomy of the discipline of history as well as to answer the question of how they understand this notion. The analysis concerns the Forum of Contemporary History Scholars that took place in Warsaw December 2016. The debate was organized to discuss the violations of the boundaries of the discipline by scholars and external actors and offers a rare insight into the way Polish historians understand their own profession. I examine the speeches of its participants with recourse to Pierre Bourdieu's theory of the field of science, particularly his concept of autonomy. My focus is on the forms of heteronomy observed by the participants of the debate. These forms are generated by four main external powers breaching the field: political power, media, education, society. The analysis reveals that all of the participants, regardless of their position in the debate, are strongly attached to the idea of autonomy. It also allows the analyst to describe multiple reconfigurations of the meaning of autonomy that enable an individual scholar to maintain the status of the defender of the discipline independence on the one hand, and on the other to articulate his or her own projection of historical scholarship.
\end{abstract}

Key words: autonomy, heteronomy, Forum of Contemporary History Scholars, theory of the field, Pierre Bourdieu

\title{
NOTA O AUTORZE
}

Jakub Muchowski - adiunkt w Zakładzie Dziejów Historiografii i Metodologii Historii Instytutu Historii Uniwersytetu Jagiellońskiego, członek Ośrodka Badań nad Kulturami Pamięci WP UJ. Zajmuje się teorią pisarstwa historycznego, historią intelektualna, historią społeczną powojnia, badaniami nad Holokaustem i ludobójstwem, historią praw człowieka i współczesną pamięcią kulturową. Jest sekretarzem redakcji czasopisma "Historyka. Studia Metodologiczne". Autor Polityki pisarstwa historycznego (Toruń 2015) i Historyki Shoah (Warszawa 2006). E-mail: jakub.muchowski@uj.edu.pl 